\title{
IMPLEMENTASI REGULASI PERHUTANAN SOSIAL YANG BERMANFAAT BAGI MASYARAKAT SEKITAR HUTAN
}

\author{
THE IMPLEMENTATION OF SOCIAL FORESTRY REGULATIONS THAT BENEFITS \\ FOR COMMUNITIES AROUND THE FOREST
}

\author{
Tasya Moedy Agusti, I Nyoman Nurjaya, Imam Koeswahyono \\ Program Studi Magister Kenotariatan Universitas Brawijaya \\ Jalan MT. Haryono 169, Malang \\ email: tasyamoedya@gmail.com
}

\begin{abstract}
Indonesian government agrarian reform program to realize equitable and development based on social justice for all the people of Indonesia, viz. the social forestry program. Legally the implementation of the social forestry program must bring maximum benefits to the community around the forest. This article uses the sociological juridical method and takes research locations in the jurisdiction of KPH Probolinggo, BKPH Senduro, and BKPH Kraksaan East Java Regional Division. The results showed that the social forestry program is very important to be implemented, but there are still some problems that need to be fixed.
\end{abstract}

Keywords: agrarian reform, social forestry, regulation

\begin{abstract}
Abstrak: artikel ini menganalisis program reformasi agraria oleh pemerintah Indonesia dalam rangka mewujudkan pemerataan dan pembangunan yang berbasis keadilan sosial bagi seluruh rakyat Indonesia, yaitu program perhutanan sosial. Secara yuridis implementasi dari program perhutanan sosial harus membawa manfaat yang sebesar-besarnya bagi masyarakat sekitar hutan. Penulisan artikel ini menggunakan metode yuridis sosiologis dengan mengambil lokasi penelitian di wilayah hukum KPH Probolinggo, BKPH Senduro dan BKPH Kraksaan Divisi Regional Jawa Timur. Hasil penelitian menunjukkan bahwa program perhutanan sosial sangat penting untuk diterapkan dan masih terdapat beberapa persoalan yang perlu untuk diperbaiki dalam implementasinya agar program perhutanan sosial membawa manfaat yang sebesar-besarnya bagi masyarakat desa di sekitar hutan.
\end{abstract}

Kata Kunci: reformasi agraria, perhutanan sosial, regulasi

\section{PENDAHULUAN}

Bangsa Indonesia dikaruniai sumber daya alam yang melimpah oleh Tuhan Yang Maha Esa. Karunia tersebut dapat dipergunakan sebagai modal pembangunan di segala bidang dengan tujuan untuk menyejahterakan masyarakat Indonesia sehingga harus dikelola, dimanfaatkan, dan dilindungi sebaik mungkin. Pengelolaan sumber daya alam tersebut, secara substansial harus mampu menyejahterakan seluruh rakyat, dan secara normatif harus berdasarkan hukum yang berlaku. Hal tersebut didasarkan pada ketentuan Pasal 1 ayat (3) UndangUndang Dasar Negara Republik Indonesia Tahun 1945 yang menyatakan bahwa Indonesia adalah negara hukum. Ketentuan ini secara konstitusional bermakna dalam menyelenggarakan kekuasaan negara harus berdasarkan hukum, artinya kekuasaan negara dibatasi oleh hukum (Fadjar, 2004), baik dalam aspek kehidupan bermasyarakat, berbangsa, dan bernegara (Fadjar, 2018). Hal tersebut membawa konsekuensi logis bahwa dalam aspek pengelolaan sumber daya alam di Indonesia harus berdasarkan dan diatur oleh hukum. 
Dasar hukum pengelolaan sumber daya alam di Indonesia terdapat dalam Pasal 33 Ayat 3 UUD NRI Tahun 1945 yang berbunyi "Bumi, air, dan kekayaan alam yang terkandung didalamnya dikuasai oleh negara dan dipergunakan untuk sebesarbesarnya kemakmuran rakyat". Salah satu sumber daya alam yang ada di Indonesia adalah hutan.

Hutan sebagai sumber daya kekayaan alam di Indonesia harus dikuasai oleh negara dan harus dipergunakan untuk mencapai sebesar-besarnya kemakmuran rakyat (Nurjaya, 2005b). Potensi hutan di Indonesia cukup besar untuk dimanfaatkan karena Indonesia merupakan negara yang memiliki hutan cukup luas, hampir 90\% hutan di dunia berada di Indonesia, sehingga Indonesia disebut sebagai paru-paru dunia (Wartiningsih, 2014).

Kehutanan di Indonesia diatur melalui hukum kehutanan. Terkait dengan regulasi hukum kehutanan, pemerintah sedang gencar-gencarnya menggulirkan program reformasi agraria dalam rangka mewujudkan pemerataan dan pembangunan yang berbasis keadilan bagi seluruh rakyat Indonesia (KLHK, 2018). Salah satu progam di ranah kehutanan yang dimiliki oleh pemerintah dalam rangka pemerataan pembangunan yang berbasis keadilan bagi rakyat Indonesia adalah program perhutanan sosial.

Menteri Lingkungan dan Kehutanan menerbitkan Peraturan Menteri Lingkungan Hidup dan Kehutanaan Republik Indonesia Nomor 83 Tahun 2016 tentang Perhutanaan Sosial dan Peraturan Menteri Lingkungan Hidup dan Kehutanaan Republik Indonesia Nomor 39 Tahun 2017 tentang Perhutanaan Sosial di Wilayah Kerja Perum Perhutani dengan tujuan memberikan kepastian hukum terhadap pelaksanaan program perhutanan sosial. Peraturan-peraturan tersebut dibuat untuk mengurangi ketimpangan penguasaan, pemilikan, penggunaan, dan pemanfaatan tanah yang mengakibatkan ketimpangan struktur ekonomi masyarakat.
Perhutanan sosial merupakan perwujudan dari Nawacita Presiden yang ketujuh yaitu mewujudkan kemandirian ekonomi dengan menggerakkan sektor-sektor strategis ekonomi domestik (Marroli, 2019). Tujuan dari perhutanan sosial adalah untuk pemerataan sektor ekonomi dalam masyarakat dan untuk mengurangi adanya ketimpangan di sektor ekonomi, yang diusahakan melalui tiga pilar yaitu lahan, pemberian kesempatan usaha, dan sumber daya manusia. Program perhutanan sosial ini memberikan akses yang legal kepada masyarakat desa di sekitar hutan untuk mengakses hutan di kawasan hutan negara melalui mekanisme penerbitan perizinan yang diterbitkan oleh menteri dalam bentuk surat keputusan (SK).

Dasar hukum pelaksanaan program perhutanan sosial (PS) adalah Pasal 2 Undang-Undang Nomor 41 Tahun 1999 tentang Kehutanan yang mengatur bahwa penyelenggaraan kehutanan harus berpegang pada asas manfaat dan lestari, asas kerakyatan, asas keadilan, asas kebersamaan, asas keterbukaan, dan asas keterpaduan. Pasal 4 ayat (1) Undang-Undang Nomor 41 Tahun 1999 tentang Kehutanan mengatur bahwa hutan beserta kekayaan alam didalamnya dikuasai oleh negara untuk kemakmuran rakyat. Pasal 21b Undang-Undang Nomor 41 Tahun 1999 menyatakan bahwa pemanfaatan hutan bertujuan untuk mendapatkan manfaat yang optimal bagi kesejahteraan seluruh masyarakat secara berkeadilan dengan tetap menjaga kelestariannya. Dari beberapa ketentuan tersebut, pengelolaan sumber daya hutan harus berbasis pada manfaat yang sebesar-besarnya bagi kemakmuran rakyat atau masyarakat desa di sekitar hutan.

Pemanfaatan hutan diatur juga dalam Pasal 1 ayat (1) Peraturan Menteri Lingkungan Hidup dan Kehutanan Nomor 83 Tahun 2016. Program perhutanan sosial terbagi menjadi beberapa program, yaitu Kemitraan Kehutanan (KK), Hutan Desa (HD), Hutan Kemasyarakatan (HKM), Hutan Tanaman Rakyat (HTR), dan Hutan Adat (HA). 
Pelaksanaan perhutanan sosial di wilayah Jawa, sebagai implikasi dari Peraturan Pemerintah Nomor 72 Tahun 2010, Lembaran Negara Republik Indonesia Tahun 2010 Nomor 124 Tentang Perusahaan Umum Kehutanan Negara (Perum Perhutani) dilimpahkan kewenangannya kepada Perum Perhutani. Program perhutanan sosial di Jawa dilakukan melalui kemitraan kehutanan.

Kemitraan kehutanan merupakan sebuah bentuk kerja sama antara pengelola hutan (Perum Perhutani) dengan masyarakat desa di sekitar hutan. Hutan di Jawa secara garis besar dibedakan menjadi dua, yaitu hutan jati dan hutan rimba (non jati) (Supriyadi, 2013). Praktiknya keduanya sama-sama dijadikan obyek perhutanan sosial.

Pada ranah praktik, perhutanan sosial dalam wujud kemitraan kehutanan dibagi menjadi dua skema (KLKH, 2019), yaitu melalui skema Kulin KK (Pengakuan dan Perlindungan Kemitraan Kehutanan) dan IPHPS (Izin Pemanfaatan Hutan Perhutanaan Sosial). Implementasi program perhutanan sosial di Jawa Timur dalam rentang waktu dua tahun, ada satu desa di Kecamatan Senduro yang mendapatkan izin pemanfaatan kawasan hutan, yakni LMDH Wonolestari yang mendapat izin perhutanan sosial melalui skema Kulin KK (KLKH, 2019). Adapun luasan program perhutanan sosial tersebut adalah 940 ha. Selanjutnya BKPH Kraksaan, dengan daerah hutan jati ada di Desa Brani Wetan Kecamatan Maron melalui skema IPHPS kepada LMDH Sumber Rejeki yang mencapai 552 ha.

Pelaksanaan program kehutanan sosial mengalami beberapa kendala. Beberapa kendala tersebut adalah: (a) terdapat penggarap lahan yang tidak berprofesi sebagai petani, (b) masalah luasan lahan yang tidak sesuai antara yang tercantum di SK dan fakta, (c) masalah penyaluran permodalan melalui kredit usaha rakyat (KUR) kepada petani, dan (d) masih terdapat konflik-konflik teritorial yang mengakibatkan implementasi program perhutanan sosial belum sepenuhnya dapat membawa kemanfaatan bagi masyarakat desa di sekitar hutan.

Berdasarkan uraian tersebut, perlu ada analisis urgensi pemanfaatan kawasan hutan yang dikelola oleh Perum Perhutani melalui program perhutanan sosial serta analisis implementasi regulasi perhutanan sosial di KPH Probolinggo BKPH Senduro (Desa Bruno) dan BKPH Kraksaan (Desa Brani Wetan) sehingga benar-benar menghadirkan manfaat bagi masyarakat sekitar hutan.

\section{METODE}

Pendekatan yang digunakan dalam penulisan artikel ini adalah pendekatan hukum yuridis empiris (Dyah \& Efendi, 2014) yaitu bentuk pengkajian hukum dalam ranah hukum kenyataan dan berlakunya hukum di masyarakat (Muhammad, 2004). Pendekatan ini ditinjau dari sudut empiris atau biasa disebut dengan yuridis sosiologis (socio legal approach) yang dilakukan dengan melihat berlakunya hukum di masyarakat (Johan, 2008; Waluyo, 2002).

Lokasi pengambilan bahan hukum adalah seluruh hutan produksi di Jawa Timur (Perum Perhutani Divisi Regional Jawa Timur). Obyek yang dipilih adalah hutan jati dan hutan rimba (non jati). Sampel pengambilan bahan hukum ditetapkan di Kabupaten Lumajang (BKPH Senduro) dan di Kabupaten Probolinggo (BKPH Kraksaan) yang masuk dalam wilayah kerja KPH Probolinggo. Dipilihnya lokasi tersebut karena mewakili keseluruhan skema perhutanan sosial melalu program Kemitraan Kehutanan antara masyarakat dengan Perum Perhutani, program perhutanan sosial di BKPH Senduro menggunakan skema Kulin KK, sedangkan BKPH Kraksaan menggunakan skema IPHPS. BKPH Senduro merupakan satu-satunya skema Kulin KK di Jawa Timur dan menjadi obyek percontohan nasional, dan skema IPHPS di BKPH Kraksaan juga merupakan salah satu program perhutanan sosial yang oleh Kementerian Lingkungan Hidup dan Kehutanan dinilai memiliki 
kesiapan yang paling baik dilihat dari segi hutannya dan kondisi sosial masyarakat setempat (Akbar, 2019).

\section{HASIL DAN PEMBAHASAN}

\section{Urgensi Pemanfaatan Kawasan Hutan yang Dikelola oleh Perum Perhutani Melalui Program Perhutanan Sosial}

Program Perhutanan Sosial (PS) di Indonesia terlahir dari proses sejarah yang panjang. Kebijakan ini merupakan implikasi dari hasil perubahan paradigma atau cara pandang masyarakat global dalam sistem pengelolaan hutan secara konvensional yang cenderung berpandangan bahwa hutan semata-mata hanyalah kayu dan habitat bagi fauna dengan menegasikan keberadaan masyarakat desa di sekitar/dalam hutan yang hidup, berinteraksi, dan bergantung terhadap hutan sebagai satu kesatuan ekosistem yang pada dasarnya antara satu dengan yang lain tidak dapat terpisahkan. Paradigma lama ini berujung pada kerusakan hutan dan kemiskinan struktural masyarakat sekitar hutan (Wicaksono, 2019). Selama ini pengelolaan hutan di Jawa berada di tangan negara yang mengeksploitasi kekayaan yang terkandung di dalamnya dengan membatasi akses petani ke sumber daya hutan (Sunderlin, 2019). Hal demikian mengakibatkan selama tiga dekade terakhir praktik pengelolaan dan pemanfaatan sumber daya hutan cenderung melahirkan konflik yang diakibatkan oleh perbedaan persepsi dan kepentingan dalam pengelolaan hutan (Nurjaya, 2005b).

Perhutanan sosial di Indonesia muncul sebagai wujud koreksi dan perlawanan terhadap monopoli pengelolaan perhutanan yang mengenyampingkan keberadaan masyarakat yang hidup di dalam maupun di sekitar hutan dan cenderung berpihak kepada pemodal besar (asing dan dalam negeri) untuk mengelola (mengeksploitasi) hutan dengan dalih pertumbuhan ekonomi. Gagasan ini memperkenalkan pendekatan baru yang berorientasi kepada kesejahteraan masyarakat desa di dalam maupun sekitar hutan. Pelibatan masyarakat lokal dalam manajemen kehutanan perlu dikedepankan sehingga terjadi perubahan paradigma pengelolaan hutan dari pengelolaan hutan oleh negara semata ke arah pengelolaan hutan bersama masyarakat, yaitu pengelolaan hutan yang harus melibatkan dan menyejahterakan masyarakat sekitar hutan.

Perhutanan sosial dimaksudkan untuk mengurangi kemiskinan, penggangguran, dan ketimpangan pengelolaan atau pemanfaatan kawasan hutan. Pemberian akses legal kepada masyarakat setempat berupa pengelolaan hutan desa, izin usaha hutan kemasyarakatan, hutan tanaman rakyat, kemitraan kehutanan atau pengakuan, dan perlindungan masyarakat hukum adat dimaksudkan untuk memberikan kesejahteraan masyarakat dan kelestarian sumber daya hutan. Hasil telaah tentang pemberian program perhutanan sosial kepada masyarakat yang bermukim di kawasan hutan memberikan indikasi bahwa pemerintah memperhatikan masyarakat yang bermukim di kawasan hutan tersebut, sebab hampir seluruh masyarakat yang bermukin di sekitar hutan berpenghasilan rendah dan diindikasi sebagai pihak yang merusak hutan (Supriadi, 2011).

Berdasarkan data dari KPH Probolinggo, BKPH Senduro Desa Bruno dan BKPH Kraksaan Desa Brani Wetan memberikan penguatan bahwa program perhutanan sosial menjadi sangat urgen untuk diimplementasikan dengan baik karena dapat menjadi solusi yang dibutuhkan oleh masyarakat desa di sekitar hutan untuk menyejahterakan kehidupan mereka. Sebelum lahirnya program perhutanan sosial, terdapat beberapa persoalan seperti pengrusakan hutan dan penjarahan hutan yang prosesnya sangat masif dan telah direncanakan dengan terstruktur oleh masyarakat. Hal tersebut disebabkan oleh tertutupnya akses masyarakat desa di sekitar hutan terhadap hutan, padahal kehidupan masyarakat desa di sekitar hutan sangat 
bergantung kepada lahan hutan tersebut. Berdasarkan pemaparan di atas maka dapat disimpulkan bahwa pemanfaatan kawasan hutan yang dikelola oleh Perum Perhutani bersama masyarakat setempat dalam program perhutanan sosial urgen untuk mengurangi kemiskinan, penggangguran, dan ketimpangan pengelolaan atau pemanfaatan kawasan hutan, serta untuk menyejahterakan masyarakat desa di sekitar hutan dan untuk mengurangi adanya konflik-konflik teritorial yang selama ini cenderung banyak terjadi dalam praktik pengelolaan hutan.

\section{Implementasi Regulasi Perhutanan Sosial di BKPH Senduro dan BKPH Kraksaan bagi Masyarakat Desa di Sekitar Hutan}

Regulasi kehutanan telah mengalami kemajuan signifikan menuju arah hukum responsif (responsive law). Pada era Orde Baru, bangunan hukum pengelolaan hutan mencerminkan ideologi pengelolaan hutan yang berbasis negara atau biasa dikenal dengan istilah state based forest management (Nurjaya, 2005). Hal tersebut tampak dalam salah satu regulasi yang dikeluarkan pemerintah Orde Baru, yaitu PP Nomor 28 Tahun 1985 tentang Perlindungan Hutan. Pasal 9 menegaskan bahwa "Selain dari petugas-petugas kehutanan atau orang-orang yang karena tugasnya atau kepentingannya dibenarkan berada di dalam kawasan hutan, siapapun dilarang membawa alat-alat yang lazim digunakan untuk memotong, menebang, dan membelah pohon di dalam kawasan hutan; setiap orang dilarang melakukan penebangan pohon-pohon dalam hutan tanpa izin dari pejabat yang berwenang; setiap orang dilarang mengambil/memungut hasil hutan lainnya tanpa izin dari pejabat yang berwenang".

Pada awal era reformasi ketentuan regulasi mengenai hukum kehutanan tidak mengalami perubahan yang signifikan. Produk hukum pada era reformasi mengandung muatan jiwa, semangat, dan substansi yang secara prinsip tidak berbeda dengan era Orde Baru. Pada tahun 2016, regulasi terbaru pada ranah hukum kehutanan lebih bersifat responsif yaitu dengan diterbitkannya Peraturan Menteri Lingkungan Hidup dan Kehutanaan Republik Indonesia Nomor 83 Tahun 2016 tentang Perhutanan Sosial dan Peraturan Menteri Lingkungan Hidup dan Kehutanaan Republik Indonesia Nomor 39 Tahun 2017 tentang Perhutanan Sosial di Wilayah Kerja Perum Perhutani. Peraturan tersebut dibuat untuk mengurangi ketimpangan penguasaan, pemilikan, penggunaan, dan pemanfaatan tanah yang mengakibatkan ketimpangan struktur ekonomi masyarakat. Hal tersebut merupakan gambaran perubahan bangunan hukum pengelolaan sumber daya hutan yang dulunya bercorak represif (repressive law) mengalami perubahan yang cukup signifikan ke arah responsif (responsive law).

Menurut ketentuan Peraturan Menteri Lingkungan Hidup dan Kehutanaan Republik Indonesia Nomor 83 Tahun 2016 dan Peraturan Menteri Lingkungan Hidup dan Kehutanaan Republik Indonesia Nomor 39 Tahun 2017, menteri dapat memberikan izin pemanfaatan hutan perhutanan sosial (IPHPS) dan pengakuan pelindungan kemitraan kehutanan (Kulin KK) kepada kelompok masyarakat dengan payung hukum surat keputusan (SK). Berdasarkan Pasal 16 Peraturan Menteri Lingkungan Hidup dan Kehutanaan Republik Indonesia Nomor 39 Tahun 2017, izin diberikan dalam jangka waktu 35 tahun. Berdasarkan ketentuan Pasal 4 ayat (1) Peraturan Menteri Lingkungan Hidup dan Kehutanaan Republik Indonesia Nomor 39 Tahun 2017 izin pemanfaatan hutan perhutanan sosial (IPHPS) diberikan bagi kawasan hutan dengan tutupan lahan di bawah atau sama dengan 10\% dalam kurun waktu lima tahun berturut-turut. Sebaliknya untuk kawasan hutan dengan tutupan lahan diatas $10 \%$ dalam kurun waktu lima tahun berturut-turut maka dikenakan pengakuan perlindungan kemitraan kehutanan (Kulin $\mathrm{KK})$. 
Berdasarkan ketentuan di atas, maka perhutanan sosial merupakan upaya pemberian akses legal kepada msyarakat setempat dalam kawasan hutan negara melalui izin pemanfaatan hutan perhutanan sosial (IPHPS) serta pengakuan dan perlindungan kemitraan kehutanan (Kulin KK) antara Perhutani selaku pengelola hutan negara di Jawa dengan masyarakat yang diwadahi oleh Lembaga Masyarakat Desa Hutan (LMDH) sebagai perhimpunan masyarakat setempat selaku mitra, yang mata pencahariannya bergantung pada kawasan hutan. Tujuanya adalah memperoleh pengakuan dan perlindungan dengan payung hukum yang kuat, mengurangi ketimpangan pengelolaan pamanfaatan hutan, ketimpangan antar wilayah dan berkurangnya pendapatan, serta perlindungan dan pemulihan ekosistem menuju kesejahteraan masyarakat (Nurhayadi, 2019).

Program perhutanan sosial ini memiliki tujuan jangka panjang memperbaiki kondisi lahan hutan yang kritis, meningkatkan partisipasi aktif masyarakat desa di sekitar hutan untuk meningkatkan kesejahteraan masyarakat, menyediakan kebutuhan masyarakat desa dari dalam hutan, dan konservasi sumber daya alam. Tujuan jangka pendeknya adalah membentuk kelompok tani di hutan, peningkatan keberhasilan tanaman, dan peningkatan pendapatan kelompok tani hutan. Salah satu harapan penting adanya program perhutanan sosial adalah meningkatkan taraf hidup masyarakat desa di sekitar hutan (Helmi, 2012). Intinya, secara teoritis pemanfaatan kawasan hutan sebagai obyek perhutanan sosial harus senantiasa membawa kesejahteraan dan kemanfaatan bagi masyarakat desa di sekitar hutan.

Implementasi program perhutanan sosial di KPH Probolinggo, yaitu BKPH Senduro Desa Bruno dan BKPH Kraksaan Desa Brani Wetan terdapat perbedaan mendasar. Program perhutanan sosial di wilayah BKPH Senduro Desa Bruno menggunakan skema
Kulin KK (pengakuan dan perlindungan kemitraan kehutanan), sedangkan untuk wilayah BKPH Kraksaan Desa Brani Wetan program perhutanan sosial menggunakan skema IPHPS (izin pemanfaatan hutan perhutanan sosial).

Praktik perhutanan sosial dilaksanakaan melalui skema kemitraan antara masyarakat desa di sekitar hutan yang diwadahi oleh LMDH (Lembaga Masyarajat Desa Hutan) dengan Perum Perhutani. Lembaga masyarakat desa hutan yang menjadi mitra Perum Perhutani dalam pelaksanaan program perhutanan sosial merupakan suatu lembaga yang dibentuk oleh masyarakat desa hutan dalam rangka kerjasama pengelolaan sumber daya hutan.

Pemberian izin program perhutanan sosial dengan skema Kulin KK di Desa Bruno BKPH Senduro diberikan melalui Keputusan Menteri Lingkungan Hidup dan Kehutanan Republik Indonesia tentang Pengakuan dan Perlindungan Kemitraan Kehutanan Nomor: SK.5633/MENLHKPSKL/PKPS/ PSL.0/10/2017 tertanggal 26 Oktober 2017, sedangkan di Desa Brani Wetan BKPH Kraksaan pemberian izin diberikan melalui Keputusan Menteri Lingkungan Hidup dan Kehutanan Republik Indonesia tentang Pemberian Izin Pemanfaatan Hutan Perhutanan Sosial Nomor: SK.3932/ MENLHK-PSKL/PKPS/PSL.0/07/2017 tertanggal 19 Juli 2017. Pemberian izin tersebut bukan merupakan pemberian kepemilikan atas kawasan hutan (owner rights) melainkan hanya izin pengelolaan (use of rights) yang merupakan penggunaan hak atas tanah berdasarkan kesepakatan tertentu yang dibuat antara pemegang hak dengan pihak ketiga. Izin pengelolaan harus dilaksanakan berdasarkan prinsip pengelolaan hutan lestari sebagaimana dimaksud Pasal 97 ayat (2) Peraturan Pemerintah Nomor 6 Tahun 2007 jo Peraturan Pemerintah Nomor 3 Tahun 2008 tentang Tata Hutan dan Penyusunan Rencana Pengelolaan Hutan, serta Pemanfaatan Hutan. 
Di lokasi kawasan perhutanan sosial dengan skema Kulin KK di Desa Bruno Kecamatan Senduro memiliki beragam jenis tanaman dan beragam jenis usaha pemanfaatan kawasan hutan, antara lain: (a) usaha di bawah tegakan atau tumpangsari, seperti tanaman talas, kaliandra, dan palawija, (b) penanaman hijau makanan ternak (HMT) seperti rumput gajah, (c) pengembangan dan pemeliharaan tanaman buah-buahan (MTPS) seperti pohon pisang, pembibitan durian, dan pembibitan alpukat, (d) usaha pemanfaatan hasil hutan bukan kayu dalam hutan tanaman seperti sapi perah, (e) UMKM produksi sale pisang, kripik pisang, susu kambing etawa senduro (etsen), biogas, dan daur ulang sampah, dan (f) usaha pemanfaatan jasa wisata alam, berupa air terjun dan jalur sepeda gunung. Hal tersebut bertolak belakang dengan kawasan perhutanan sosial dengan skema IPHPS pada kawasan Hutan Jati di Desa Brani Wetan yang hanya memiliki empat jenis tanaman yaitu agro forestry berupa padi, tanaman semusim berupa tembakau, tanaman kayu berupa sengon, dan tanaman MTPS berupa cabai.

Implementasi program perhutanan sosial dengan beberapa jenis kegiatan tersebut membawa konsekuensi logis adanya hak dan kewajiban dari para pihak, yaitu hak dan kewajiban LMDH Wonolestari selaku pemegang izin perhutanan sosial. Kewajiban LMDH Wonolestari antara lain: (a) mentaati perjanjian kerjasama baik mikro dan makro yang dibuat oleh para pihak, yang dalam praktiknya perjanjian kerjasama tersebut disebut sebagai NKK (Naskah Kesepakatan Kerjasama), (b) menjaga arealnya dari perusakan dan pencemaran lingkungan, (c) melakukan penanaman dan pemeliharaan hutan di areal kemitraan kehutanan, (d) mempertahankan fungsi hutan, (e) melaksanakan fungsi keamanan dan perlindungan hutan, yang dalam praktiknya juga dijaga, dilindungi, dan diawasi masyarakat desa di sekitar hutan yang merasa menggantungkan hidupnya sehingga berdampak pada semakin lestarinya fungsi ekologi dari hutan karena terhindar dari perusakan, (f) pembayaran penerimaan negara bukan pajak (PNBP) dan pajak bumi dan bangunan (PBB) yang dibebankan kepada perum perhutani. Hak LMDH Wonolestari antara lain: (a) melakukan kegiatan pada areal yang telah diberikan pengakuan dan perlindungan kemitraan kehutanan, (b) mendapat perlindungan dari gangguan perusakan dan pencemaran lingkungan atau pengambil alihan secara sepihak oleh pihak lain, (c) memanfaatkan areal kemitraan kehutanan sesuai dengan fungsinya, (d) mendapatkan pendampingan dalam kegiatan pemanfaatan, penyuluhan, teknologi, akses pembiayaan, dan pemasaran, dan (e) mendapatkan hasil usaha pemanfaatan kemitraan kehutanan.

Kewajiban LMDH Sumber Rejeki selaku pemegang izin perhutanan sosial dengan skema izin pemanfaatan hutan perhutanan sosial (IPHPS) antara lain: (a) menjaga arealnya dari perusakan dan pencemaran lingkungan, (b) memberi tanda batas area kerja, (c) menyusun rencana pemanfaatan jangka panjang selama 10 tahun dan jangka pendek selama satu tahun, (d) melakukan penanaman dan pemeliharaan hutan di area kerjanya, (f) melaksanakan tata usaha hasil hutan, (g) mempertahankan fungsi hutan, (h) melaksanakan fungsi perlindungan, (i) membayar penerimaan negara bukan pajak (PNBP) sesuai dengan ketentuan perundang-undangan, (j) membayar pajak bumi dan bangunan (PBB) sesuai ketentuan perundang-undangan. Hak LMDH Sumber Rejeki adalah sebagai berikut: (a) melakukan kegiatan pada areal yang telah diberikan IPHPS, (b) mendapat perlindungan dari gangguan perusakan dan pencemaran lingkungan atau pengambilalihan secara sepihak oleh pihak lain, (c) mengelola, dan memanfaatkan areal hutan sesuai dengan fungsinya, (d) mendapatkan pendampingan 
dalam kegiatan pemanfaatan, penyuluhan, teknologi, akses pembiayaan, dan pemasaran, dan (e) mendapatkan hasil usaha pemanfaatan.

Praktik program perhutanan sosial menghadapi tiga kendala yang mengakibatkan pelaksanaannya kurang membawa manfaat bagi masyarakat desa di sekitar hutan. Pertama, terdapat penggarap lahan yang bukan berprofesi sebagai petani. Pada praktiknya memang hanya beberapa orang yang tidak berprofesi sebagai petani yang mendapatkan lahan karena adanya kedekatan secara personal dengan pejabat-pejabat terkait. Pengelolaan hutan penyediaan fasilitas tertentu dimonopoli oleh oknum tertentu yang juga mendapatkan keuntungan berupa lahan garapan yang seharusnya untuk masyarakat desa di sekitar hutan. Jika ditinjau secara normatif hal ini tentu bertentangan dengan regulasi yang ada yaitu ketentuan dalam Pasal 1 angka 5 Permen LHK Nomor 39 tahun 2017 yang menyatakan bahwa penggarap adalah petani yang mata pencaharian utama mengerjakan lahan secara langsung.

Kedua, masalah luas lahan yang tidak sesuai antara yang tercantum di SK dan fakta yang ada. Berdasarkan ketentuan dalam Pasal 41 ayat (1) Permen LHK Nomor 83 Tahun 2016 areal untuk kemitraan kehutanan paling luas adalah dua hektar untuk setiap kepala keluarga dan Pasal 15 Permen LHK Nomor 39 Tahun 2017 yang menyatakan IPHPS dilaksanakan oleh anggota kelompok dengan luas lahan garapan maksimal dua hektar. Masalah yang kemudian muncul adalah luasan lahan yang tertulis pada SK tidak sesuai dengan fakta yang ada sehingga saat ada verifikasi dari pihak lembaga keuangan Bank BRI dalam kaitannya dengan permodalan, masyarakat mengalami kesulitan, karena dalam proses verifikasi kebenaran data calon penerima Kredit Usaha Rakyat (KUR) tidak memberikan hasil yang positif.

Ketiga, masalah penyaluran Kredit Usaha Rakyat (KUR). Masyarakat mendapatkan bantuan permodalan dari lembaga keuangan Bank BRI untuk wilayah Jawa, dalam bentuk KUR Tahunan dan KUR Musiman. Masalah terjadi saat penyaluran KUR yaitu adanya penyalahgunaan oleh oknum-oknum tertentu yang memegang jabatan di lembaga (LMDH). Beberapa problematika tersebut antara lain: (a) semua kartu ATM untuk menyalurkan KUR dari Bank kepada petani dipegang oleh ketua LMDH sehingga terjadi penyalahgunaan oleh beberapa oknum, (b) pada saat pencairan dana KUR musiman untuk satu hektar tanah seharusnya petani memperoleh dana 14 juta, namun hanya diberi tujuh juta oleh oknum tertentu dan sisanya akan diberikan pada musim selanjutnya, padahal penarikan dana yang dilakukan oleh oknum tersebut adalah sebesar 14 juta namun hanya disalurkan tujuh juta pada petani, (c) ada persoalan yang terjadi antara masyarakat dengan Perum Perhutani, khususnya untuk daerah perhutanan sosial dengan skema IPHPS, misalnya masyarakat mengeluhkan ada sebagian lahannya yang tidak dapat digarap karena masih terdapat tegakan sisa tumbuhan kayu jati milik Perum Perhutani.

Implementasi program perhutanan sosial dikaitkan dengan ketentuan konstitusional Pasal 33 ayat (3) UUD NRI Tahun 1945 dan Undang-Undang Nomor 41 Tahun 1999 tentang Kehutanan mengamanatkan hutan sebagai sumber daya kekayaan alam di Negara Indonesia pada tingkatan yang tertinggi dikuasai oleh negara sebagai organisasi kekuasaan dan harus dipergunakan untuk mencapai sebesar-besarnya kemakmuran rakyat dalam arti kesejahteraan dalam masyarakat (Nurjaya, 2005a).

Berdasarkan Pasal 2 Undang-Undang Nomor 41 Tahun 1999 penyelenggaraan kehutanan harus dilakukan dengan berpegang pada asas manfaat dan lestari, asas kerakyatan, asas keadilan, asas kebersamaan, asas keterbukaan, dan asas keterpaduan dengan dilandasi akhlak mulia dan bertanggung gugat. Ketentuan tersebut mengatur penyelenggaraan 
kehutanan senantiasa harus mengandung semangat kerakyatan yang berkeadilan dan berkelanjutan. Asas manfaat dan lestari maksudnya agar dalam setiap kegiatan penyelenggaraan kehutanan memperhatikan adanya sebuah keseimbangan dan kelestarian unsur lingkungan, keseimbangan sosial dan budaya, serta keseimbangan ekonomi sehingga bermanfaat dalam memberikan kebahagiaan dan kemakmuran yang sebesar-besarnya bagi masyarakat dari aspek ekonomi, sosial, dan sosiologis (perilaku masyarakat).

Menurut Bhentam sebagai penggagas aliran hukum utilitarianisme, sebuah hukum baru diakui sebagai hukum jika hukum tersebut memberi kemanfaatan yang sebesar-besarnya untuk sebanyak-banyaknya masyarakat (Rasjidi \&Rasjidi, 2001). Apabila dianalisis lebih lanjut dengan yang dikemukakan Bentham, maka baik atau buruknya sebuah hukum harus diukur dari baik atau buruknya akibat yang ditimbulkan dari penerapan hukum itu. Hukum dapat dinilai sebagai hukum yang baik jika akibat yang dihasilkan dari implementasi atau penerapaan hukum tersebut adalah kebaikan dan kebahagiaan yang sebesar-besarnya dan berkurangnya penderitaan. Menurut teori ini tujuan hukum adalah untuk mencapai kesejahteraan yang sebesar-besarnya bagi sebanyak-banyaknya masyarakat atau apabila dapat untuk seluruh masyarakat (Rasdjidi \& Rasdjidi, 2001).

Hasil implementasi program perhutanan sosial yang ada di wilayah hukum KPH Probolinggo Divisi Regional Jawa Timur, BKPH Senduro untuk skema pengakuan dan perlindungan kemitraan kehutanan (Kulin KK) Desa Bruno, dan BKPH Kraksaan untuk skema izin pemanfaatan hutan perhutanan sosial (IPHPS) Desa Brani Wetan belum sepenuhnya dapat membawa kemanfaatan bagi masyarakat desa di sekitar hutan karena adanya oknum-oknum yang tidak bertanggung jawab dan kondisi lahan yang kurang dapat dimanfaatkan. Walaupun demikian, secara umum pelaksanaan perhutanan sosial sudah menunjukkan keberhasilan. Sebelum adanya perhutanan sosial, kecenderungan perilaku masyarakat adalah perusak hutan dan mencuri hasil hutan, karena memang masyarakat desa yang menggantungkan hidupnya kepada hutan tidak memiliki pilihan lain. Akan tetapi dengan adanya program perhutanan sosial, pola perilaku masyarakat berubah dan masyarakat desa di sekitar hutan berbalik menjadi penjaga hutan.

Sebelum adanya program perhutanan sosial, perilaku penyelenggaraan hutan di kedua lokasi tersebut menggambarkan perilaku yang tidak berlandaskan kepada akhlak mulia, seperti maraknya penjarahan massal pada hutan dan perusakan lahan hutan. Hal tersebut disebabkan karena bangunan hukum pengelolaan kehutanan yang ada di Indonesia menggambarkan hukum yang mencerminkan ideologi pengelolaan hutan yang berbasis negara (state-based forest management) yang bercorak represif (repressive law) dan ada sanksi ancaman pidana bagi masyarakat yang tanpa izin masuk ke dalam hutan. Pengelolaan hutan berbasis negara mengakibatkan masyarakat yang menggantungkan hidupnya kepada hutan melakukan kegiatan yang masif dan terstruktur dengan menjarah dan merusak hutan. Misalnya penjarahan massal pada hutan yang terjadi pada tahun 1998-1999 yang berlanjut sampai tahun 2006 di Desa Bruno hingga terbentuk LMDH sebagai wadah bagi masyarakat desa di sekitar hutan. Saat ini, program perhutanan sosial mampu memperbaiki perilaku masyarakat desa di sekitar hutan.

Dengan demikian, program perhutanan sosial memiliki urgensi agar berkelanjutan dan diberlakukan melalui mekanisme evaluasi yang baik dari kementerian. Pendampingan secara masif dan berkala kepada masyarakat pemegang izin perhutanan sosial baik dari kementerian, pemerintah, Perum Perhutani, dan akademisi sangat diperlukan 
untuk meningkatkan pelaksanaan program perhutanan sosial dan meminimalisir permasalahan-permasalahan yang terjadi.

\section{SIMPULAN}

Urgensi program perhutanan sosial bagi masyarakat adalah untuk mengurangi kemiskinan, penggangguran, dan ketimpangan pengelolaan atau pemanfaatan kawasan hutan, menyejahterakan masyarakat desa di sekitar hutan, dan untuk mengurangi adanya konflik-konflik teritorial yang selama ini cenderung banyak terjadi dalam praktik pengelolaan hutan. Pelaksanaan perhutanan sosial menggunakan dua skema, yaitu Kulin KK (Pengakuan dan Perlindungan Kemitraan Kehutanan) dan IPHPS (Izin Pemanfaatan Hutan Perhutanan Sosial. Masalah yang dihadapi adalah beberapa penerima lahan bukan petani, luas lahan tidak sama antara SK dengan luas lahan yang digarap, dan dana KUR yang diperoleh tidak diberikan seluruhnya secara langsung kepada petani. Pelaksanaan perhutanan sosial telah mengurangi penjarahan dan perusakan hutan karena masyarakat hutan memiliki pekerjaan dan penghasilan.

\section{DAFTAR RUJUKAN}

Akbar, S. (2019). Menteri LHK Tinjau Lokasi IPHPS Hutan Petak Brani Wetan. http://probolinggokab.go.id

Dyah, O., \& Efendi, A. (2014). Penelitian Hukum (Legal Research). Jakarta: Sinar Grafika.

Fadjar, A. M. (2004). Tipe Negara Hukum. Malang: Buyumedia.

Fadjar, A. M. (2018). Menuju Negara Bermartabat. Malang: Intrans Publishing.

Helmi. (2012). Hukum Perizinan Lingkungan Hidup. Jakarta: Sinar Grafika.

Johan, B. (2008). Metode Penelitian Ilmu Hukum. Bandung: CV. Mandar Maju. KLKH. (2018). KLHK siap luncurkan
Instrumen Teknis TORA. http://www. menlhk.go.id

KLKH, B. (2019). Perhutanan Sosial di Senduro, Kabupaten Lumajang. http:// bp2sdm.menlhk.go.id

Marroli. (2019). Perhutanan Sosial, Kini Masyarakat Legal Mengelola Hutan. https://kominfo.go.id/

Muhammad, A. K. (2004). Hukum dan Penelitian Hukum. PT. Citra Aditya Bakti.

Nurhayadi. (2019). Peran Penyuluh dalam Implementasi Kulin KK. http:// bp2sdmk.dephut.go.id

Nurjaya, I. N. (2005a). Magersari: Dinamika Komunitas Petani-Petani Hutan dalam Prespektif Antropologi Hukum. Malang: IKIP Malang.

Nurjaya, I. N. (2005b). Sejarah Hukum Pengelolaan Hutan Di Indonesia. Jurnal Jurisprudence, 2(1), 35-55.

Rasdjidi, L., \& Rasdjidi, I. (2001). DasarDasar Filsafat dan Teori Hukum. Bandung: Citra Aditya Bakti.

Sunderlin, W. D. (2019). Nancy Lee Peluso Rich Forests, Poor People: Resource Control and Resistance in Java. Berkeley, Los Angeles, Oxford: University of California Press 1992. http://ecommons.cornell.edu

Supriadi. (2011). Hukum Kehutanan dan Hukum Perkebunan di Indonesia. Jakarta: Sinar Grafika.

Supriyadi, B. E. (2013). Hukum Agraria Kehutanan aspek hukum Pertanahan dalam Pengelolaan Hutan Negara. Jakarta: PT. Rajagrafindo Persada.

Waluyo, B. (2002). Penelitian Hukum dalam Praktik. Jakarta: Sinar Grafika.

Wartiningsih. (2014). Pidana Kehutanan. Malang: Setara Press.

Wicaksono, R. L. (2019). Target (Ambisius) Kebijakan Perhutanan Sosial: Antara Idealita dan Realita. https://kehutanan. unja.ac.id 